PENGEMBANGAN MODEL BERMAIN BAGI ANAK-ANAK UNTUK MENINGKATKAN TEKNIK KUMITE DALAM OLAHRAGA KARATE PADA MASA LOCKDOWN COVID-19 (Widha Srianto-Yudi Karisma Sari)

\title{
PENGEMBANGAN MODEL BERMAIN \\ BAGI ANAK-ANAK UNTUK MENINGKATKAN TEKNIK KUMITE \\ DALAM OLAHRAGA KARATE PADA MASA LOCKDOWN COVID-19
}

\author{
Widha Srianto \\ Yudi Karisma Sari
}

\author{
Penjas FKIP UTP SURAKARTA \\ widha.srianto@lecture.utp.ac.id
}

\begin{abstract}
ABSTRAK
Penelitian ini bertujuan untuk menghasilkan model bermain untuk meningkatkan teknik kumite bagi anak-anak dalam masa lockdown, dan mendukung anak-anak untuk aktif berolahraga selama masa lockdown karena virus covid-19 dan menghasilkan model bermain untuk melatih teknik kumite yang menyenangkan. Penelitian pengembangan ini dilakukan dengan mengadaptasi langkah-langkah penelitian sebagai berikut: (1) pengumpulan informasi di lapangan, (2) melakukan analisis terhadap informasi yang telah dikumpulkan, (3) mengembangkan produk awal, (4) validasi ahli dan revisi, (5) uji coba produk dan revisi, (6) uji coba pemakaian dan revisi, dan (7) pembuatan produk final. Uji coba skala kecil dilakukan di dojo Inkanas Fighter Hagen. Uji coba skala besar dilakukan di Inkanas Daerah Istimewa Yogyakarta. Instrumen pengumpulan data yang digunakan yaitu: (1) pedoman observasi model, (2) pedoman observasi keefektifan model. Teknik analisis data yang dilakukan yaitu analisis deskriptif kuantitatif dan analisis deskriptif kualitatif.

Hasil penelitian ini berupa model bermain dirumah untuk meningkatkan teknik kumite, yaitu: (1) model bermain tali untuk melatih maegeri, (2) bermain memindahkan balok untuk melatih mawashigeri, (3) model bermain melempar bola untuk melatih gyaku tsuki, dan (4) model bermain memasukkan bola dalam keranjang untuk melatih oi tsuki. Dari hasil analisis data penilaian para ahli memberi kesimpulan bahwa model dinilai baik dan efektif, sehingga model latihan yang dikembangkan layak untuk digunakan.
\end{abstract}

Kata kunci: model bermain, karate, covid-19

\section{PENDAHULUAN}

Olahraga menjadi salah satu kegiatan yang digunakan membangun karakter bangsa (sport nation and character building). Sebagai contoh, bermain secara fair play dalam kompetisi olahraga dapat diaplikasikan pada perilaku sehari-hari. Oleh karena itu, olahraga dapat digunakan sebagai sarana membangun karakter bangsa. Masa covid-19 menuntut semua orang melakkukan social distancing, sehingga semua aktifitas yang bersifat masa, baik sekolah, bekerja, aktifitas social, maupun olahraga yang biasa dilakukan secara bersamaan harus di hentikan (lockdown) sehingga hal ini menjadikan suatu permasalahan yang berdampak, salah satunya adalah kegiatan latihan yang dilakukan anak-anak harus diliburkan secara bersama-sama. Dari hasil wawancara yang dilakukan dengan pelatih dan dapat 
PENGEMBANGAN MODEL BERMAIN BAGI ANAK-ANAK UNTUK MENINGKATKAN TEKNIK KUMITE DALAM OLAHRAGA KARATE PADA MASA LOCKDOWN COVID-19 (Widha Srianto-Yudi Karisma Sari)

disimpulkan beberapa permasalahan: (1) pada masa covid-19 anak tidak memiliki motivasi berlatih (2) perlu model bermain selama masa covid-19, dan (3) karate menjadi alternatif sarana bermain untuk anakp-anak pada masa covid-19. Penelitian pengembangan ini bertujuan mengasilkan suatu model bermain untuk meningkatak teknik kumite dalam olahraga karate, sehingga anak-anak pada masa lockdown tetap bisa bermain dan berolahraga.

Dari uraian diatas dapat dipahami bahwa masa anak-anak adalah masa emas penuh dengan keceriaan dan canda tawa dengan teman lainnya, dan masa lockdon karena covid-19 menjadikan anak tidak punya gairah untuk berolahraga dan merasa bosan, sehingga penelitian ini menjadikan suatu alternative untuk mengembangan model bermain untuk meningkatkan teknik dalam olahraga karate, sehingga dengan bermain anak tetap senang dan tetap berlatih karate.

\section{TINJAUAN PUSTAKA}

\section{Bermain / Permainan}

Diartikan bahwa permainan diidentifikasikan sebagai setiap kegiatan yang dipilih secara bebas, termotivasi dari dalam diri sediri, dan diarahkan secara pribadi. Aktivitas ini berada di luar kehidupan biasanya, dan bersifat tidak serius tetapi pada saat yang sama pemain menyerap secara intens. Seifert \& Hoffnung (Paiman, 2009: 278) menyatakan bahwa: Bermain adalah dunia anak-anak yang berlangsung dalam kurun waktu yang cukup panjang. Pada usia enam tahun, kemampuan motoriknya sudah mulai berkembang lebih kompleks, yaitu dapat berjalan dengan berbagai variasi kecepatan, loncat, menggeser, memanjat, memindahkan sesuatu dengan tepat, berdiri satu kaki, menangkap bola, dan menggambar sesuatu, maka latihan yang sesuai dengan ketrampilan tersebut dapat dilakukan.

\section{Karate.}

Inti sari dari teknik karate adalah gerak penentu atau kime, yaitu sebuah serangan atau tangkisan yang meledak ke sasaran yang dituju dengan penggunaan teknik yang tepat dan tenaga yang maksimum dalam waktu yang sesingkat-singkatnya. Kime dapat dilakukan dengan tangan untuk memukul atau menangkis. Adapun pertandingan resmi dalam olahraga karate terbagi menjadi dua yaitu Kata dan Kumite. Sedangkan pengertian kumite menurut (Nakayama, 1986: 14) "Kumite is a method of training in which the offensive and defensive 
PENGEMBANGAN MODEL BERMAIN BAGI ANAK-ANAK UNTUK MENINGKATKAN TEKNIK KUMITE DALAM OLAHRAGA KARATE PADA MASA LOCKDOWN COVID-19 (Widha Srianto-Yudi Karisma Sari)

learned in the kata are given practical application". Diartikan bahwa Kumite adalah pertarungan karate, dimana dari setiap teknik yang dilakukan harus mengenai sasaran.

\section{Covid -19}

COVID-19 (sebelumnya disebut dengan 2019-nCov) adalah virus jenis baru yang belum pernah diidentifikasi sebelumnya pada manusia. Mengingat masih terbatasnya informasi tentang karakteristik COVID-19 maka strategi pencegahan dan pengendalian infeksi digunakan untuk mencegah atau membatasi penularan infeksi dengan menerapkan kewaspadaan terhadap kontak, percikan dahak langsung (droplet) dan penularan melalui udara (airborne).

\section{METODOLOGI PENELITIAN}

\section{Jenis Penelitian}

Penelitian ini merupakan penelitian pengembangan atau Research and Development adalah metode penelitian yang digunakan untuk menghasilkan produk tertentu dan menguji keefektifan produk tersebut.

\section{Prosedur Pengembangan}

Ada beberapa model penelitian pengembangan, menurut Borg \& Gall (2003) penelitian dan pengembangan dilakukan melalui 10 tahap, meliputi : Penelitian dan Pengumpulan Data, Perencanaan, Uji Coba Lapangan Awal, Revisi Hasil Uji Coba, Uji Coba Produk , Revisi Produk, Uji Coba Pemakaian, Revisi Produk Final, Desiminasi dan Implementasi

\section{Uji Coba Produk}

Dalam penelitian ini uji coba dilakukan sebanyak dua kali, yaitu uji coba produk dan uji coba pemakaian. Subjek coba dalam penelitian ini adalah anak-anak yang memiliki klasifikasi anak-anak dengan usia dibawah 14 tahun. Data yang dikumpulkan dari penelitian ini adalah data dari expert judgment dari hasil melalui observasi video dengan menggunakan angket. Data kuantitatif berasal dari data: (1) lembar observasi model, (2) lembar observasi keefektifan model. Data kualitatif berasal dari (1) data wawancara pada saat observasi awal, dan (2) data masukan oleh expert judgment. 
PENGEMBANGAN MODEL BERMAIN BAGI ANAK-ANAK UNTUK MENINGKATKAN TEKNIK KUMITE DALAM OLAHRAGA KARATE PADA MASA LOCKDOWN COVID-19 (Widha Srianto-Yudi Karisma Sari)

\section{HASIL PENELITIAN DAN PEMBAHASAN}

\section{Analisis Data}

Dari hasil penilaian expert judgment terhadap draf awal, model yang dikembangkan telah sesuai dinyatakan layak untuk diujicobakan.

\section{Uji Coba Produk}

\section{Bermain tali untuk melatih tendangan maegeri}

Penilaian expet judgment terhadap data hasil uji coba produk dipaparkan pada tabel berikut:

Tabel 6:

Data hasil observasi

\begin{tabular}{|l|c|c|c|c|c|c|c|c|c|c|c|}
\hline \multirow{2}{*}{$\begin{array}{l}\text { Ahli } \\
\text { materi }\end{array}$} & \multicolumn{10}{|c|}{ Item Klasifikasi } & \multirow{2}{*}{$\begin{array}{c}\text { Total } \\
\text { Nilai }\end{array}$} \\
\cline { 2 - 15 } & $\mathbf{1}$ & $\mathbf{2}$ & $\mathbf{3}$ & $\mathbf{4}$ & $\mathbf{5}$ & $\mathbf{6}$ & $\mathbf{7}$ & $\mathbf{8}$ & $\mathbf{9}$ & $\mathbf{1 0}$ & \\
\hline Pakar 1 & 4 & 3 & 4 & 4 & 3 & 4 & 4 & 4 & 3 & 3 & $\mathbf{3 6}$ \\
\hline Pakar 2 & 4 & 4 & 3 & 3 & 4 & 4 & 4 & 4 & 3 & 4 & $\mathbf{3 7}$ \\
\hline
\end{tabular}

Tabel 7:

Uji keefektifan

\begin{tabular}{|l|c|c|c|c|c|c|c|c|c|c|c|}
\hline \multirow{2}{*}{$\begin{array}{l}\text { Ahli } \\
\text { materi }\end{array}$} & \multicolumn{10}{|c|}{ Item Klasifikasi } & \multirow{2}{*}{$\begin{array}{c}\text { Total } \\
\text { Nilai }\end{array}$} \\
\cline { 2 - 12 } & $\mathbf{1}$ & $\mathbf{2}$ & $\mathbf{3}$ & $\mathbf{4}$ & $\mathbf{5}$ & $\mathbf{6}$ & $\mathbf{7}$ & $\mathbf{8}$ & $\mathbf{9}$ & $\mathbf{1 0}$ & \\
\hline Pakar 1 & 4 & 3 & 4 & 4 & 3 & 4 & 4 & 3 & 3 & 3 & $\mathbf{3 3}$ \\
\hline Pakar 2 & 4 & 4 & 3 & 3 & 4 & 4 & 4 & 4 & 3 & 3 & $\mathbf{3 6}$ \\
\hline
\end{tabular}

Berdasarkan hasil penilaian expert judgment dimasukkan ke dalam norma kategori, maka penilaian yang dilakukan oleh expert judgment dalam kategori tinggi dan efektif.

\section{Bermain melempar bola untuk melatih gyakutsuki}

Penilaian expet judgment terhadap data hasil uji produk dipaparkan pada tabel berikut:

Tabel 8:

Data hasil observasi

\begin{tabular}{|l|c|c|c|c|c|c|c|c|c|c|c|}
\hline \multirow{2}{*}{$\begin{array}{l}\text { Ahli } \\
\text { materi }\end{array}$} & \multicolumn{10}{|c|}{ Item Klasifikasi } & Total \\
\cline { 2 - 12 } & $\mathbf{1}$ & $\mathbf{2}$ & $\mathbf{3}$ & $\mathbf{4}$ & $\mathbf{5}$ & $\mathbf{6}$ & $\mathbf{7}$ & $\mathbf{8}$ & $\mathbf{9}$ & $\mathbf{1 0}$ & Nilai \\
\hline Pakar 1 & 3 & 3 & 4 & 4 & 3 & 4 & 4 & 3 & 3 & 3 & $\mathbf{3 4}$ \\
\hline Pakar 2 & 4 & 3 & 3 & 3 & 4 & 4 & 4 & 4 & 3 & 3 & $\mathbf{3 5}$ \\
\hline
\end{tabular}


PENGEMBANGAN MODEL BERMAIN BAGI ANAK-ANAK UNTUK MENINGKATKAN TEKNIK KUMITE DALAM OLAHRAGA KARATE PADA MASA LOCKDOWN COVID-19 (Widha Srianto-Yudi Karisma Sari)

Tabel 9:

Uji keefektifan

\begin{tabular}{|l|c|c|c|c|c|c|c|c|c|c|c|}
\hline Ahli & \multicolumn{10}{|c|}{ Item Klasifikasi } & Total \\
\cline { 2 - 11 } materi & $\mathbf{1}$ & $\mathbf{2}$ & $\mathbf{3}$ & $\mathbf{4}$ & $\mathbf{5}$ & $\mathbf{6}$ & $\mathbf{7}$ & $\mathbf{8}$ & $\mathbf{9}$ & $\mathbf{1 0}$ & Nilai \\
\hline Pakar 1 & 4 & 3 & 4 & 4 & 3 & 4 & 4 & 4 & 4 & 4 & $\mathbf{3 6}$ \\
\hline Pakar 2 & 4 & 4 & 3 & 3 & 4 & 4 & 4 & 4 & 4 & 4 & $\mathbf{3 8}$ \\
\hline
\end{tabular}

Berdasarkan hasil penilaian expert judgment dimasukkan ke dalam norma kategori, maka penilaian yang dilakukan oleh expert judgment dalam kategori tinggi dan efektif.

\section{Bermain memindahkan balok untuk melatih mawashigeri}

Penilaian expet judgment terhadap data hasil uji coba produk dipaparkan pada tabel berikut:

Tabel 10

Data hasil observasi

\begin{tabular}{|l|c|c|c|c|c|c|c|c|c|c|c|}
\hline \multirow{2}{*}{$\begin{array}{l}\text { Ahli } \\
\text { materi }\end{array}$} & \multicolumn{10}{|c|}{ Item Klasifikasi } & \multirow{2}{*}{$\begin{array}{l}\text { Total } \\
\text { Nilai }\end{array}$} \\
\cline { 2 - 14 } & $\mathbf{1}$ & $\mathbf{2}$ & $\mathbf{3}$ & $\mathbf{4}$ & $\mathbf{5}$ & $\mathbf{6}$ & $\mathbf{7}$ & $\mathbf{8}$ & $\mathbf{9}$ & $\mathbf{1 0}$ & \\
\hline Pakar 1 & 4 & 3 & 4 & 4 & 3 & 4 & 4 & 4 & 4 & 4 & $\mathbf{3 8}$ \\
\hline Pakar 2 & 4 & 4 & 4 & 4 & 4 & 4 & 4 & 4 & 3 & 3 & $\mathbf{3 8}$ \\
\hline
\end{tabular}

Tabel 11:

Uji keefektifan

\begin{tabular}{|l|c|c|c|c|c|c|c|c|c|c|c|}
\hline \multirow{2}{*}{$\begin{array}{l}\text { Ahli } \\
\text { materi }\end{array}$} & \multicolumn{10}{|c|}{ Item Klasifikasi } & \multicolumn{1}{c|}{$\begin{array}{c}\text { Total } \\
\text { Nilai }\end{array}$} \\
\cline { 2 - 12 } & $\mathbf{1}$ & $\mathbf{2}$ & $\mathbf{3}$ & $\mathbf{4}$ & $\mathbf{5}$ & $\mathbf{6}$ & $\mathbf{7}$ & $\mathbf{8}$ & $\mathbf{9}$ & $\mathbf{1 0}$ & \\
\hline Pakar 1 & 4 & 4 & 4 & 4 & 3 & 4 & 4 & 4 & 4 & 4 & $\mathbf{3 9}$ \\
\hline Pakar 2 & 4 & 4 & 3 & 4 & 4 & 4 & 3 & 4 & 4 & 4 & $\mathbf{3 8}$ \\
\hline
\end{tabular}

\section{Bermain melempar bola dalam keranjang untuk melatih oitsuki}

Penilaian expet judgment terhadap data hasil uji coba produk dipaparkan pada tabel berikut:

Tabel 12:

Data hasil observasi

\begin{tabular}{|l|c|c|c|c|c|c|c|c|c|c|c|}
\hline \multirow{2}{*}{$\begin{array}{l}\text { Ahli } \\
\text { materi }\end{array}$} & \multicolumn{10}{|c|}{ Item Klasifikasi } & Total \\
\cline { 2 - 13 } & $\mathbf{1}$ & $\mathbf{2}$ & $\mathbf{3}$ & $\mathbf{4}$ & $\mathbf{5}$ & $\mathbf{6}$ & $\mathbf{7}$ & $\mathbf{8}$ & $\mathbf{9}$ & $\mathbf{1 0}$ & Nilai \\
\hline Pakar 1 & 4 & 3 & 4 & 4 & 3 & 4 & 4 & 4 & 4 & 4 & $\mathbf{3 8}$ \\
\hline Pakar 2 & 4 & 4 & 4 & 4 & 4 & 4 & 4 & 4 & 4 & 3 & $\mathbf{3 9}$ \\
\hline
\end{tabular}

Jurnal IImiah SPIRIT, ISSN; 1411-8319 Vol. 20 No. 02 Tahun 2020 
PENGEMBANGAN MODEL BERMAIN BAGI ANAK-ANAK UNTUK MENINGKATKAN TEKNIK KUMITE DALAM OLAHRAGA KARATE PADA MASA LOCKDOWN COVID-19 (Widha Srianto-Yudi Karisma Sari)

Tabel 13:

Uji keefektifan

\begin{tabular}{|c|c|c|c|c|c|c|c|c|c|c|c|}
\hline \multirow{2}{*}{$\begin{array}{l}\text { Ahli } \\
\text { materi }\end{array}$} & \multicolumn{10}{|c|}{ Item Klasifikasi } & \multirow{2}{*}{$\begin{array}{l}\text { Total } \\
\text { Nilai }\end{array}$} \\
\hline & 1 & 2 & 3 & 4 & 5 & 6 & 7 & 8 & 9 & 10 & \\
\hline Pakar 1 & 4 & 4 & 4 & 4 & 4 & 4 & 4 & 3 & 4 & 4 & 39 \\
\hline Pakar 2 & 4 & 3 & 3 & 4 & 4 & 4 & 4 & 4 & 4 & 4 & 38 \\
\hline
\end{tabular}

Berdasarkan hasil penilaian expert judgment dimasukkan ke dalam norma kategori. Penyajian norma kategori sebagai berikut disajikan dalam tabel.

Tabel 14:

Kategorisasi skor (Saifudin, 2004: 109)

\begin{tabular}{|c|c|c|}
\hline Formula & Batasan & Kategori \\
\hline$X<(\mu-1,0 \sigma)$ & $X<20$ & Rendah \\
\hline$(\mu-1,0 \sigma) \leq X<(\mu+1,0 \sigma)$ & $20 \leq X<30$ & Sedang \\
\hline$(\mu+1,0 \sigma) \leq X$ & $30 \leq X$ & Tinggi \\
\hline
\end{tabular}

Berdasarkan hasil penilaian expert judgment dimasukkan ke dalam norma kategori, maka penilaian yang dilakukan oleh expert judgment dalam kategori tinggi dan efektif.

\section{Data Masukan Expert Judgment}

Data masukan dari ahli materi pada uji coba produk terhadap pengembanga model bermain bagi anak-anak untuk meningkatkan teknik kumite dalam olahraga karate pada masa lockdown covid-19.

Tabel 15:

Data masukan penelitian skala kecil

\begin{tabular}{|l|l|}
\hline \multicolumn{1}{|c|}{ Ahli Materi } & \multicolumn{1}{c|}{ Masukan } \\
\hline $\begin{array}{l}\text { Expert judgment } \\
\text { (akedimisi) }\end{array}$ & - \\
\hline Expert judgment 2 (praktisi) & $\begin{array}{l}\text { Dilakukan pembenahan terhadap lemparan } \\
\text { untuk menyesuaikan tekniknya. }\end{array}$ \\
\hline
\end{tabular}

\section{Analisis Data Uji Coba Produk}

Berdasarkan analisis data yang didapatkan dalam uji coba produk baik observasi terhadap materi dan uji keefektifan dihasilkan penilaian bidang praktisi yaitu bahwa permainan harus di kontrol agar lemparan / tendangan yang dilakukan saat bermain sesuai dengan tujuan yaitu melatih teknik yang akan dilatihkan. 
PENGEMBANGAN MODEL BERMAIN BAGI ANAK-ANAK UNTUK MENINGKATKAN TEKNIK KUMITE DALAM OLAHRAGA KARATE PADA MASA LOCKDOWN COVID-19 (Widha Srianto-Yudi Karisma Sari)

Data Uji Coba Pemakaian

Bermain melompati tali untuk melatih maegeri

Penilaian expert judgment terhadap data hasil uji coba pemakaian dipaparkan pada tabel berikut:

Tabel 16:

Data hasil observasi

\begin{tabular}{|l|c|c|c|c|c|c|c|c|c|c|c|}
\hline \multirow{2}{*}{$\begin{array}{l}\text { Ahli } \\
\text { materi }\end{array}$} & \multicolumn{10}{|c|}{ Item Klasifikasi } & \multirow{2}{*}{$\begin{array}{c}\text { Total } \\
\text { Nilai }\end{array}$} \\
\cline { 2 - 15 } & $\mathbf{1}$ & $\mathbf{2}$ & $\mathbf{3}$ & $\mathbf{4}$ & $\mathbf{5}$ & $\mathbf{6}$ & $\mathbf{7}$ & $\mathbf{8}$ & $\mathbf{9}$ & $\mathbf{1 0}$ & 4 \\
\hline Pakar 1 & 4 & 4 & 4 & 4 & 4 & 4 & 4 & 4 & 4 & 4 & $\mathbf{4 0}$ \\
\hline Pakar 2 & 4 & 4 & 4 & 4 & 4 & 4 & 4 & 4 & 4 & 4 & $\mathbf{4 0}$ \\
\hline
\end{tabular}

Tabel 17:

Uji keefektifan

\begin{tabular}{|l|c|c|c|c|c|c|c|c|c|c|c|}
\hline \multirow{2}{*}{$\begin{array}{l}\text { Ahli } \\
\text { materi }\end{array}$} & \multicolumn{7}{|c|}{ Item Klasifikasi } & \multirow{2}{*}{\begin{tabular}{c} 
Total \\
\cline { 2 - 11 } Nilai
\end{tabular}} \\
\cline { 2 - 11 } & $\mathbf{1}$ & $\mathbf{2}$ & $\mathbf{3}$ & $\mathbf{4}$ & $\mathbf{5}$ & $\mathbf{6}$ & $\mathbf{7}$ & $\mathbf{8}$ & $\mathbf{9}$ & $\mathbf{1 0}$ & $\mathbf{3 9}$ \\
\hline Pakar 1 & 4 & 4 & 4 & 4 & 3 & 4 & 4 & 4 & 4 & 4 & 4 \\
\hline Pakar 2 & 4 & 4 & 4 & 4 & 4 & 4 & 4 & 4 & 4 & 4 & $\mathbf{4 0}$ \\
\hline
\end{tabular}

Berdasarkan hasil penilaian expert judgment dimasukkan ke dalam norma kategori, maka penilaian yang dilakukan oleh expert judgment dalam kategori tinggi dan efektif.

\section{Bermain melempar bola untuk melatih gyakutsuki}

Penilaian expet judgment terhadap data hasil uji coba pemakaian dipaparkan pada tabel berikut:

Tabel 18:

Data hasil observasi

\begin{tabular}{|l|c|c|c|c|c|c|c|c|c|c|c|}
\hline \multirow{2}{*}{$\begin{array}{l}\text { Ahli } \\
\text { materi }\end{array}$} & \multicolumn{10}{|c|}{ Item Klasifikasi } & \multirow{2}{*}{$\begin{array}{c}\text { Total } \\
\text { Nilai }\end{array}$} \\
\cline { 2 - 14 } & $\mathbf{1}$ & $\mathbf{2}$ & $\mathbf{3}$ & $\mathbf{4}$ & $\mathbf{5}$ & $\mathbf{6}$ & $\mathbf{7}$ & $\mathbf{8}$ & $\mathbf{9}$ & $\mathbf{1 0}$ & \\
\hline Pakar 1 & 4 & 4 & 4 & 4 & 4 & 4 & 4 & 4 & 4 & 4 & $\mathbf{4 0}$ \\
\hline Pakar 2 & 4 & 4 & 4 & 4 & 4 & 4 & 4 & 4 & 4 & 4 & 4 \\
\hline
\end{tabular}

Tabel 19:

Uji keefektifan

\begin{tabular}{|l|c|c|c|c|c|c|c|c|c|c|c|}
\hline \multirow{2}{*}{$\begin{array}{l}\text { Ahli } \\
\text { materi }\end{array}$} & \multicolumn{10}{|c|}{ Item Klasifikasi } & \multirow{2}{*}{$\begin{array}{c}\text { Total } \\
\text { Nilai }\end{array}$} \\
\cline { 2 - 15 } & $\mathbf{1}$ & $\mathbf{2}$ & $\mathbf{3}$ & $\mathbf{4}$ & $\mathbf{5}$ & $\mathbf{6}$ & $\mathbf{7}$ & $\mathbf{8}$ & $\mathbf{9}$ & $\mathbf{1 0}$ & $\mathbf{4 0}$ \\
\hline Pakar 1 & 4 & 4 & 4 & 4 & 4 & 4 & 4 & 4 & 4 & 4 & 4 \\
\hline Pakar 2 & 4 & 4 & 4 & 4 & 4 & 4 & 4 & 4 & 4 & 4 & 40 \\
\hline
\end{tabular}

Jurnal IImiah SPIRIT, ISSN; 1411-8319 Vol. 20 No. 02 Tahun 2020 
PENGEMBANGAN MODEL BERMAIN BAGI ANAK-ANAK UNTUK MENINGKATKAN TEKNIK KUMITE DALAM OLAHRAGA KARATE PADA MASA LOCKDOWN COVID-19 (Widha Srianto-Yudi Karisma Sari)

Berdasarkan hasil penilaian expert judgment dimasukkan ke dalam norma kategori, maka penilaian yang dilakukan oleh expert judgment dalam kategori tinggi dan efektif.

\section{Bermain mengambil balok untuk melatih mawashigeri}

Data Penilaian expet judgment terhadap data hasil uji coba pemakaian dipaparkan pada tabel berikut:

Tabel 20:

Data hasil observasi

\begin{tabular}{|l|c|c|c|c|c|c|c|c|c|c|c|}
\hline \multirow{2}{*}{$\begin{array}{l}\text { Ahli } \\
\text { materi }\end{array}$} & \multicolumn{10}{|c|}{ Item Klasifikasi } & \multirow{2}{*}{$\begin{array}{c}\text { Total } \\
\text { Nilai }\end{array}$} \\
\cline { 2 - 14 } & $\mathbf{1}$ & $\mathbf{2}$ & $\mathbf{3}$ & $\mathbf{4}$ & $\mathbf{5}$ & $\mathbf{6}$ & $\mathbf{7}$ & $\mathbf{8}$ & $\mathbf{9}$ & $\mathbf{1 0}$ & $\mathbf{4 0}$ \\
\hline Pakar 1 & 4 & 4 & 4 & 4 & 4 & 4 & 4 & 4 & 4 & 4 & $\mathbf{4 0}$ \\
\hline Pakar 2 & 4 & 4 & 4 & 4 & 4 & 4 & 4 & 3 & 4 & 4 & $\mathbf{3 9}$ \\
\hline
\end{tabular}

Tabel 21:

Uji keefektifan

\begin{tabular}{|l|c|c|c|c|c|c|c|c|c|c|c|}
\hline \multirow{2}{*}{$\begin{array}{l}\text { Ahli } \\
\text { materi }\end{array}$} & \multicolumn{10}{|c|}{ Item Klasifikasi } & \multirow{2}{*}{$\begin{array}{c}\text { Total } \\
\text { Nilai }\end{array}$} \\
\cline { 2 - 14 } & $\mathbf{1}$ & $\mathbf{2}$ & $\mathbf{3}$ & $\mathbf{4}$ & $\mathbf{5}$ & $\mathbf{6}$ & $\mathbf{7}$ & $\mathbf{8}$ & $\mathbf{9}$ & $\mathbf{1 0}$ & \\
\hline Pakar 1 & 4 & 4 & 4 & 4 & 4 & 4 & 4 & 4 & 4 & 4 & $\mathbf{4 0}$ \\
\hline Pakar 2 & 4 & 4 & 4 & 4 & 4 & 4 & 4 & 4 & 4 & 4 & $\mathbf{4 0}$ \\
\hline
\end{tabular}

Berdasarkan hasil penilaian expert judgment dimasukkan ke dalam norma kategori, maka penilaian yang dilakukan oleh expert judgment dalam kategori tinggi dan efektif.

\section{Bermain melempar bola dalam keranjang untuk melatih oitsuki}

Data Penilaian expet judgment terhadap data hasil uji coba pemakaian dipaparkan pada tabel berikut:

Tabel 22:

Data hasil observasi

\begin{tabular}{|l|c|c|c|c|c|c|c|c|c|c|c|}
\hline \multirow{2}{*}{$\begin{array}{l}\text { Ahli } \\
\text { materi }\end{array}$} & \multicolumn{10}{|c|}{ Item Klasifikasi } & \multirow{2}{*}{$\begin{array}{c}\text { Total } \\
\text { Nilai }\end{array}$} \\
\cline { 2 - 14 } & $\mathbf{1}$ & $\mathbf{2}$ & $\mathbf{3}$ & $\mathbf{4}$ & $\mathbf{5}$ & $\mathbf{6}$ & $\mathbf{7}$ & $\mathbf{8}$ & $\mathbf{9}$ & $\mathbf{1 0}$ & $\mathbf{4 0}$ \\
\hline Pakar 1 & 4 & 4 & 4 & 4 & 4 & 4 & 4 & 4 & 4 & 4 & 4 \\
\hline Pakar 2 & 4 & 4 & 4 & 4 & 4 & 4 & 4 & 4 & 4 & 4 & 40 \\
\hline
\end{tabular}

Tabel 23:

Uji keefektifan

\begin{tabular}{|l|c|c|c|c|c|c|c|c|c|c|c|}
\hline \multirow{2}{*}{$\begin{array}{l}\text { Ahli } \\
\text { materi }\end{array}$} & \multicolumn{10}{|c|}{ Item Klasifikasi } & \multirow{2}{*}{$\begin{array}{c}\text { Total } \\
\text { Nilai }\end{array}$} \\
\cline { 2 - 15 } & $\mathbf{1}$ & $\mathbf{2}$ & $\mathbf{3}$ & $\mathbf{4}$ & $\mathbf{5}$ & $\mathbf{6}$ & $\mathbf{7}$ & $\mathbf{8}$ & $\mathbf{9}$ & $\mathbf{1 0}$ & \\
\hline Pakar 1 & 4 & 4 & 4 & 4 & 4 & 4 & 4 & 4 & 4 & 4 & $\mathbf{4 0}$ \\
\hline Pakar 2 & 4 & 4 & 4 & 4 & 4 & 4 & 4 & 4 & 4 & 4 & 4 \\
\hline
\end{tabular}

Jurnal IImiah SPIRIT, ISSN; 1411-8319 Vol. 20 No. 02 Tahun 2020 
PENGEMBANGAN MODEL BERMAIN BAGI ANAK-ANAK UNTUK MENINGKATKAN TEKNIK KUMITE DALAM OLAHRAGA KARATE PADA MASA LOCKDOWN COVID-19 (Widha Srianto-Yudi Karisma Sari)

Berdasarkan hasil penilaian expert judgment dimasukkan ke dalam norma kategori. Penyajian norma kategori sebagai berikut disajikan dalam tabel.

Tabel 24:

Kategorisasi skor (Saifudin, 2004: 109)

\begin{tabular}{|c|c|c|}
\hline Formula & Batasan & Kategori \\
\hline$X<(\mu-1,0 \sigma)$ & $X<20$ & Rendah \\
\hline$(\mu-1,0 \sigma) \leq X<(\mu+1,0 \sigma)$ & $20 \leq X<30$ & Sedang \\
\hline$(\mu+1,0 \sigma) \leq X$ & $30 \leq X$ & Tinggi \\
\hline
\end{tabular}

Berdasarkan hasil penilaian expert judgment dimasukkan ke dalam norma kategori, maka penilaian yang dilakukan oleh expert judgment dalam kategori tinggi dan efektif.

\section{Data Masukan Expert Judgment}

Data masukan dari ahli materi pada uji coba pemakaian terhadap model latihan adalah sebagai berikut:

Tabel 25:

Data masukan expert judgment

\begin{tabular}{|l|c|}
\hline \multicolumn{1}{|c|}{ Ahli Materi } & Masukan \\
\hline Expert Judgment 1 (akademisi) & - \\
\hline Expert Judgment 2 (praktisi) & - \\
\hline
\end{tabular}

\section{Analisis Data Uji Coba Pemakaian}

Penilaian expert judgment dalam uji coba pemakaian pada skor tinggi (baik), dan tidak revisi dan masukkan, artinya bahwa pengembangan model bermain bagi anak-anak untuk meningkatkan teknik kumite dalam olahraga karate pada masa lockdown covid-19 sangat efektif dan dari hasil analisis tersebut maka hasil uji coba pemakaian tidak perlu direvisi dan layak untuk digunakan.

Jurnal IImiah SPIRIT, ISSN; 1411-8319 Vol. 20 No. 02 Tahun 2020 


\section{Revisi Produk Akhir:}

Bermain melompati tali

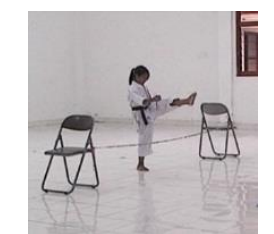

Gambar 1: bermain tali

Bermain melempar bola untuk melatih gyaku tsuki

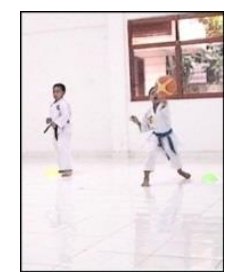

Gambar 2: bermain melempar bola

Model bermain mengambil balok untuk melatih mawashi geri

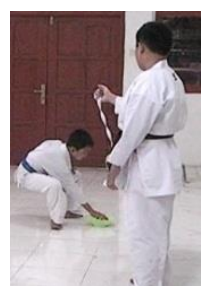

Gambar 3: bermain mengambil balok

Bermain melempar bola dalam keranjang untuk melatih teknik oi tsuki

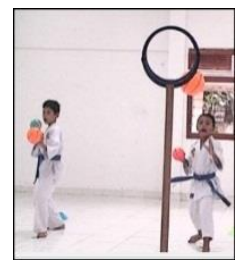

Gambar 4: bermain melempar bola dalam keranjang

\section{Revisi Uji Coba Pemakaian}

Dari penilaian ahli materi dan pelatih terhadap instrumen observasi serta keefektifan pada uji coba produk, para ahli materi dan pelatih sependapat bahwa pengembangan model bermain untuk meningkatkan teknik kumite dalam olahraga karate pada masa lockdown covid-19 dalam kategori baik dan efektif. sehingga tidak diperlukan revisi. 
PENGEMBANGAN MODEL BERMAIN BAGI ANAK-ANAK UNTUK MENINGKATKAN TEKNIK KUMITE DALAM OLAHRAGA KARATE PADA MASA LOCKDOWN COVID-19 (Widha Srianto-Yudi Karisma Sari)

\section{Kajian Produk Akhir}

Setelah mendapat penilaian dan masukan baik dari para ahli materi maupun dari pelatih, serta dilakukan proses-proses revisi terhadap draf model. Akhirnya dihasilkan model bermain untuk meningkatkan teknik kumite dalam olahraga karate pada masa lockdown covid-19 yang layak digunakan.

\section{SIMPULAN}

Penelitian ini manghasilkan suatu produk berupa model bermain untuk meningkatkan teknik kumite dalam olahraga karate pada masa lockdown covid-19, hasil analisis dan penilaian para expert judgment disimpulkan bahwa:

1. Menghasilkan model bermain tali untuk melatih teknik maegeri yang layak untuk digunakan

2. Menghasilkan model bermain melempar bola untuk melatih teknik gyaku tsuki yang layak untuk digunakan

3. Menghasilkan model bermain mengambil balok untuk melatih teknik mawashi geri yang layak untuk digunakan.

4. Menghasilkan model bermain melempar bola ke dalam keranjang untuk melatih teknik oi tsuki yang layak untuk digunakan.

\section{DAFTAR PUSTAKA}

Andang Ismail. (2009). Education Games Panduan Praktis Permainan Yang Menjadikan Anak Anda Cerdas, Kratif, Dan Saleh. Yogyakarta: Pro-U Media..

Borg, Walter R. \& Gall., M.D. (2003). Educational Research. (an introduction 7th ed). New York \& London: Longman.

Djemari Mardapi. (2008). Teknik Penyusunan Instrumen Tes Dan Nontes. Yogyakarta: Mitra Cendikia Press.

Lantz Jim. (2002). Family Development And The Martial Arts: A Phenemonological Study. Colombus: Human science press, inc.

Paiman. (2009). Olahraga Dan Kebugaran Jasmani (Physical Fitness) Pada Anak Usia Dini. Jurnal Cakrawala Pendidikan, XXVIII, 3, 270-281.

Saifuddin Azwar. (2004). Penyusunan Skala Psikologi. Yogyakarta: Pustaka Pelajar Offset.

Sugeng Purwanto (2009). Pembinaan Prestasi Olahraga Karate. Yogyakarta: Jurnal iptek olahraga, 11, 2, 171-181.

Jurnal IImiah SPIRIT, ISSN; 1411-8319 Vol. 20 No. 02 Tahun 2020 

MASA LOCKDOWN COVID-19 (Widha Srianto-Yudi Karisma Sari)

Sugiyono. (2011). Metode Penelitian Pendidikan: Pendekatan Kuantitatif, Kualitatif, Dan R \& D. Bandung: Alfabeta.

Theeboom Marc \& Knop Paul De. (2006). Asian Martial Arts And Approaches Of Instruction In Physical Education. European journal of physical education, 4:2, 146-161. 